\title{
Clinical Supervision Based on Spiritual Quotient to Improve the Performance of Madrasah Teachers
}

\author{
Siti Thowiyah 1, Yurnalis Etek 2, Sulthan Syahril 3, Ahmad Fauzan 4, Koderi5 \\ DOI: $10.35445 /$ alishlah.v13i3.1399
}

\section{Article Info}

Keywords:

Clinical Supervision, Spiritual Quotient, Teacher Performance

Kata kunci:

Supervisi klinis, spiritual quotient, kinerja guru

\begin{abstract}
The research aimed to analyze the implementation of clinical supervision based on spiritual quotient in improving teachers' performance at State Madrasah Aliyah of Way Kanan Lampung. The research method used was descriptive qualitative. The informants in the research were principals, teachers, and supervisors. The data collections were observation, interviews, and documentation. Furthermore, it was analyzed through three stages: data presentation, data reduction, and data collection. The research showed that first, clinical supervision based on Spiritual Quotient had not been implemented, but ordinary supervision was often implemented. Second, clinical supervision based on Spiritual Quotient adapted to the diversity of teachers will impact self-awareness of their duties, so it was able to improve teachers' performance. The research implications for teachers were self-awareness, a strong desire to change for the better, and overcoming obstacles.
\end{abstract}

\begin{abstract}
Abstrak
Penelitian ini bertujuan untuk menganalisis pelaksanaan supervisi klinis berbasis spiritual quotient dalam meningkatkan kinerja guru pada Madrasah Aliyah Negeri Way Kanan Lampung. Metode penelitian yang digunakan adalah kualitatif deskriptif. Informan dalam penelitian ini adalah kepala madrasah, guru, dan pengawas. Pengumpulan data dilakukan melalui observasi, wawancara, dan dokumentasi. Selanjutnya dianalisis melalui tiga tahapan yaitu penyajian data, reduksi data, dan pengambilan data. Penelitian ini menunjukkan bahwa pertama, pelaksanaan supervisi klinis berbasis spiritual quotient belum dilaksanakan, namun yang sering dilaksanakan adalah supervisi biasa. Kedua, supervisi klinis berbasis spiritual quotient yang disesuaikan dengan keberagamaan guru akan berdampak pada kesadaran diri akan tugasnya sehingga dapat meningkatkan kinerja guru. Adapun implikasi penelitian ini terhadap guru adalah menyadari dirinya, keinginan yang kuat untuk berubah ke arah yang lebih baik, dan dapat mengatasi rintangan.
\end{abstract}

\footnotetext{
${ }^{1}$ UIN Raden Intan Lampung, Indonesia Email: sitithowiyah@gmail.com 2 UIN Raden Intan Lampung, Indonesia Email: yurnalis.etek@radenintan.ac.id 3 UIN Raden Intan Lampung, Indonesia Email: sulthan.syahril@radenintan.ac.id 4 UIN Raden Intan Lampung, Indonesia Email: ahmad.fauzan@radenintan.ac.id 5 UIN Raden Intan Lampung, Indonesia Emaill: koderi@radenintan.ac.id
} 


\section{INTRODUCTION}

The quality of education in Indonesia was essential to produce quality resources. Therefore, improvement efforts need to be done continuously (Lailatussaadah, 2015). One of the factors that influenced the quality was the teacher, so the teacher became very important in the world of education (Makhsun, 2020). To produce graduates who had comprehensive abilities, students were asked for mastering the expected competencies. Therefore, the teacher's active role needed to master the competence completely. Teachers played an essential role in achieving the quality of education. From the several components of education, teachers were the spearhead who were very decisive in the education system (Mansir, 2020) therefore teachers must be the main concern. To improve the world of education, it can be started by the teacher (Trisoni, 2016). Improving the quality of teachers was the same as improving the quality of education. What needs to be improved is its competence to give learning innovations in the classroom (Ibda, 2017). Teacher competence must be improved all the time because of the changing times that are increasingly advanced, so adjustments were needed.

One of the main abilities that teachers must possess is managing learning to learn, known as pedagogic competence. This ability started from planning learning, managing learning programs, managing classes, utilizing learning media/resources, managing communication, and doing learning assessments (Hoerotunnisa, 2021). From this ability, it can be seen whether the teacher's performance was good or not. Good teacher performance can be seen from the success of teachers in changing student behaviour.

In realizing good teacher performance, the supervisor's role was very important through clinical supervision activities. Clinical supervision was professional assistance given systematically to teachers based on the teacher's needs to foster teachers and improve professionalism in doing the learning process (Sari et al., 2017). The supervision was done to foster teacher performance in managing learning in the classroom. The principal or supervisor did clinical supervision. The supervision was done to improve teachers' performance, especially from the administrative side. Learning administration included planning, implementation, monitoring, and evaluation activities (Arif, 2008). When conducting supervision, the principal or supervisor assessed what had been planned and implemented in the learning process in the classroom.

Assessment of learning in the classroom with clinical supervision was done to assess student achievement, teacher performance assessment, alternative assessment, authentic assessment, and portfolio assessment (Arifin, 2012). The supervision was done to see the teacher's performance and the success of students in achieving the learning objectives that had been set in each subject.

Madrasa teacher performance was still low. The average post-certification teacher performance was still below the minimum standard of performance both overall and seen from the indicators of lesson planning, learning implementation, learning assessment, and professional development. There was no difference in performance after obtaining professional allowances through the teacher certification program both between teachers madrasah and religion teachers in public schools, between teachers living in urban areas and teachers living in rural areas, and between teachers who passed certification through the portfolio pathway and teachers who passed through the education and professional training pathway (PLPG) (Khodijah, 2013). Furthermore, there was no significant difference in teacher performance with the status of civil servants and non-civil servants (Aisyah T, 2017; Nastiti, 2016). The low performance of teachers was caused by several factors, including the lack of teacher motivation, teachers who taught not by scientific disciplines, salaries and supervision that had not been maximized.

One of the factors that caused low teacher performance was that the clinical supervision done by principals and supervisors had not been maximized. This was reinforced by the results of interviews that supervision had been ever done but not routinely and not properly scheduled. Although the implementation of clinical supervision by supervisors (principals) had not been maximized, teachers were being active and trying to find solutions to the teaching problems they 
faced. It was suspected that other factors were quite dominant in teacher performance, including the Spiritual Quotient factor.

Clinical supervision by combining the concept of Spiritual Quotient was certainly closely related to coaching in order to improve the performance of madrasa teachers. The implementation of clinical supervision was a combination of spiritual intelligence that was done continuously in its development to motivate to improve the teaching and learning process and feedback in learning. Clinical supervision based on Spiritual Quotient (SQ) was a supervisor who supervised the supervised teacher in a class by first giving spiritual or spiritual provisions to the teacher, so they were fully aware that teaching was a mandated task from Allah SWT.

Several previous types of research had been conducted, including Putriasih (2020) research which found that clinical supervision based on the Tri Hita Karana (THK) concept can improve teacher performance, Andani (2017), Rohmatika (2017), and Simanjuntak (2021). Clinical supervision based on a spiritual quotient distinguished it from previous research. Clinical supervision based on Spiritual Quotient can be an alternative to the development of clinical supervision. The spiritual quotient is supervision to improve teacher performance, which had appropriate stages and was conducive to its implementation guaranteed by the quality of education. Spiritual quotient was an educator's continuous professional development strategy that used the principle of collegiality. For this reason, the authors gave input so that in the implementation of supervision they can apply the concept of Clinical supervision based on Spiritual Quotient because Spiritual Quotient (SQ) was very appropriate because of this clinical supervision was done by supervisors before doing supervision in the class, such as giving the training first to all teachers with spiritual intelligence training.

\section{METHODS}

The research used descriptive qualitative. This research was conducted at State Madrasah Aliyah of Way Kanan Lampung from July to October 2019, starting from the preparation, research, and completion stages. The informants in the research were the principal, supervisors, and subject teachers. The school was chosen because it had used clinical supervision but had not shown significant progress in teacher performance because clinical supervision had not been based on Spiritual Quotient. The instrument was a clinical supervision instrument. The method of data collection was done by non-participant observation, free guided interviews, and documentation. Data analysis was done through three stages: data reduction, data presentation, and drawing conclusions or verification.

\section{FINDINGS AND DISCUSSION}

\section{Implementation of Clinical Supervision based on Spiritual Quotient}

Clinical supervision implemented the principal function as a supervisor to improve teacher performance's ability optimally in achieving the expected learning objectives. Clinical supervision led to improved quality of learning in the classroom. The goal of clinical supervision was professional assistance to teachers through systematic planning, careful observation, and objective and direct feedback. Mr. Markidi said that:

"In the early stages of supervision which usually took place, the teacher didn't pay much attention, because sometimes I didn't schedule it, due to some activities outside the madrasa."

A supervisor in doing supervision must prepare a plan in advance. In this case, the supervisor had the nature of explaining, listening, solving a problem, and negotiating. Mr. Markidi explained that:

"Clinical supervision was a sign that I wanted the madrasa that I lead to be better, of course its implementation by following the applicable system." 
What the madrasa principal did in order to instill discipline, motivation and religious studies on teachers through clinical supervision. Mr. MK said that:

"I knew that clinical supervision was supervision done by principal to find out how far the teacher's personality in learning and all administration fulfilled. In supervision I also gave input so that in the teaching and learning process, the implementation was better as expected by the government."

Furthermore, Mr. MK added that:

"In general, clinical supervision was guidance, instruction and evaluation given to teachers in order to improve the quality of the teacher's learning process in order to obtain optimal student learning outcomes. Before that, principal also made a work program for the principal included a planning program which included annual programs, semester programs, and academic supervision."

Clinical supervision was done not without reason or need. Of course, clinical supervision was chosen to carry out with the aim of achieving government expectations. According to Mr. MK, the reasons for choosing clinical supervision that was implemented as follows:

"The consideration of doing clinical supervision was on the basis of teacher requests and duties as principal. I implemented the two clinical supervisions as the principal according to the type of problems encountered. All problems must be followed up immediately by being resolved using the appropriate method and not necessarily with clinical supervision."

Mrs. Bielda said that:

"Clinical supervision was a part or form of professional teacher guidance given by the principal to teachers systematically based on their needs in order to achieve the expected goals."

Furthermore, Mrs. SM said that:

"Clinical supervision was done so that teachers can do their duties as well as possible, especially for those who experienced certain difficulties so that they can complete them as well as possible."

Thus, clinical supervision was a part of supervision in which the activities were done professionally and systematically by the principal to the teacher, so the form of guidance done by the principal was by the needs of each teacher. On the other hand, Mr. Markidi said that:

"The principal had the task of leading teachers to improve teaching, responding to and paying attention to teacher developments in the revision of educational goals, learning materials and teaching methods and assessments."

Mr. MK said that:

"Supervisors usually visited us at the beginning of the school year and in their visitation they conveyed the supervisor's work program for one academic year and one semester."

Furthermore, Mr. Markidi said that:

"Supervision was monitoring activity in order to find out that all activities in the school can be carried out according to the plan, either yearly or semester. As a madrasa supervisor, I always analyzed the strengths and weaknesses of both the annual and semester plans because there were potential opportunities to support the improvement and development of the quality of madrasa education at present and in the future."

Clinical supervision was an option because of the great desire to give guidance to teachers so that teachers could solve all the problems and difficulties they face. 
Mr. MK Kanan also said that:

"With the implementation of clinical supervision, teachers began to be motivated in doing their duties and responsibilities, as educators who were nurtured and imitated, all of which will serve as role models for their students such as discipline in going to work, discipline in entering and leaving class, at break time they also still pay attention to their students by monitoring from a distance. Essentially clinical supervision can change teacher behavior for the better."

On the other hand, Mr. MK said that:

"Teacher performance was important in doing their duties as a teacher in schools where the important role of a teacher was to be a role model for their students, whether outside the classroom, in the classroom or in the school environment. In particular, I was as a s principal as well as a teacher supervisor, like it or not, the position I hold must be able to show an example for my subordinates because I was as a teacher supervisor must show my good performance in all fields, especially referring to the 8 educational standards that I must apply, because all of this will be seen by my teachers and staff. unconsciously everything will have a positive and negative impact on my teachers and staff. This was where I had to be able to show an example for my teacher and by itself will be a good example for my teachers and staff of course this will also affect the implementation of the teacher's duties in teaching. My hope as the principal as well as a supervisor was that my teacher can improve performance."

The head of the madrasa had shown who he was and what his position was. It meant that what the head of the madrasa will do had led to spiritual quotients and good character, namely a conscience that rested on the cause of Allah SWT.

Mrs. SM said:

"Yes, my madrasa principal was very good. Even though at first we were reluctant and better to be quiet, but now it's good. He has mingled with the teacher either in the teacher's room or in the school environment, so we as teachers began to say hello, dare to express my shortcomings in teaching the class and also about the syllabus and lesson plans."

Mrs. SM says that:

"Our principal was our role model as well as our supervisor. He was a nice person, authoritative, disciplined and did not discriminate against teachers. He was also smart, well-dressed, always smiling and we were no longer afraid to see him, even though it used to look scary but now it was not. So when we wanted clinical supervision, some teachers consciously asked for supervision. The principal as supervisor sat with us, discussing the problems we were experiencing both in class and outside the classroom. He really guided us in all things related to learning."

The head of the madrasa, the supervisor, and the supervisor had shown exemplarily in doing their duties; all of this will certainly impact the effectiveness in doing their duties both the head of the madrasa or the teachers. Teachers already felt comfortable with the head of the madrasa so that it could foster teacher motivation and awareness in doing their duties which made the teacher's task more effective. Clinical supervision was supervision done by fostering by what all teachers needed. Therefore, this implementation will differ from one teacher to another. The implementation of clinical supervision will certainly be different from supervision in general.

Based on the observations, it was found that the teacher's performance was still very lacking, seen from the lesson planning and the use of learning methods. Some teachers did not make a Lesson Plan (RPP) when sudden supervision was done. It was also found that teachers did not understand in-depth how to make lesson plans correctly. Meanwhile, to improve teacher performance, teachers 
were administrators in guiding and learning in schools. In this regard, in the learning plan, the teacher was obliged to make a lesson plan as Mrs. SM said:

"Teachers were required to make learning administration which contained an educational calendar, learning time allocations, annual programs, semester programs, syllabus, lesson plans, teaching daily journals, and assessments. Because there needed to be careful planning and the implementation of learning activities can run effectively and efficiently."

Before the teacher carried out learning, the teacher was required to prepare learning media first so that learning could run systematically, effectively and efficiently. For this reason, with a learning plan, as a basic reference for implementing learning in the classroom, the teaching and learning process will be able to run well. Mrs. SM added that:

"We were as the teachers to make learning media before the teaching and learning process took place. All of this was in order to create the learning objectives expected by the government."

Furthermore, Mrs. BL said that:

"We also made media planning, strategy planning, learning resource planning and evaluation planning."

One of the requirements to become a professional teacher in teaching was making lesson plans as a teacher reference in teaching face to face with students in the learning process in the classroom, so that all teaching was well planned and the learning process will run systematically. As Mrs. Beilda stated:

"All teachers must be able to manage their pedagogical competence because professional teachers were those who were able to manage student learning which consisted of teaching, guiding (classroom, laboratory, and field), directing, training, evaluating, developing students in actualizing various potentials that had been developed. A teacher was also required to be able to manage, care for, develop and use educational media and learning facilities. In developing pedagogic competence, appropriate strategies, methods, learning techniques, guidance and potential development of students were needed."

The professionalism of the teacher's performance was largely determined by the level of the teacher's ability which was reflected in his daily behavior in the madrasa. A high level of teacher ability will more quickly lead to the achievement of madrasa goals that was planned before; on the contrary if the level of teacher ability was low the tendency of madrasa goals to be achieved will be slow and even deviate from the first plan. Competence was a fundamental factor possessed by someone who had more abilities needed to do job with good quality. The value of professionalism in work was shown in a disciplined, competent, and timely manner with the best results. Mr MK said:

"It was very important to have a professional attitude because it will produce better work and teachers will automatically get an appreciation for their achievements." "I was as a supervisor in doing clinical supervision by applying clinical methods based on good relations between peers, it was indicated that there were some teachers who still complained in writing lesson plans and using teaching methods and techniques, these problems were then discussed together and found solutions to the results joint decision. I used three cycles in analyzing this, namely the early stage, then we observed and the last stage was the feedback stage. When fostering pedagogic competence, I used several strategies, methods/models, learning techniques, guidance and development of the right student potential, including individual techniques, namely I observed lesson plan made by the teacher. In addition, I observed class with a collaborative approach, besides that I used private conversation techniques with the teacher after they had already taught, in addition 
to using individual techniques in fostering pedagogic competence, I also used group techniques, namely holding workshops, seminars and scientific forums."

On the other hand, the supervisor also said that:

"A teacher was also required to be able to use madrasa facilities by their respective fields of expertise. In addition to being able to use all teachers, they must be able to manage, maintain, develop and use educational media and learning facilities. On the other hand, there were still some teachers who had not used learning media properly and had not managed the class well."

Spiritual quotient or spiritual intelligence was a person's ability to feel and listen to his inner conscience, in the form of good and bad and the moral sense he had in how he was able to place himself in everyday life. As stated by Mr. MK that:

"Spiritual quotient was an imagination of the spiritual power of the soul. All teachers must have a good spiritual quotient spirit because with the spiritual quotient teacher will automatically understand himself, his own responsibilities, and know his position. Thus the teacher will be called himself when there were teaching hours, not only present but really present because of the soul of Allah SWT."

Spiritual quotient was needed by teachers and a number of morals and faith to be used as a tool in doing their duties and life in the natural world. Basically, a teacher's performance must have an influence for someone in doing it, which was a big motivation and made it the main thing that must be in every teacher's soul because with high motivation, the teacher will be able to do tasks without having a madrasa head, without asking for praise, without asking anyone to see, but purely a call from the soul. Mr. MK said that:

"I did hopes for my teacher that the spiritual quotient or spiritual intelligence should have been embedded in my teacher, for that the teacher will automatically teach with the schedule that had been made, of course, all of that will be done well, the teacher had a lot of tasks and it was not easy, one of which must give an example for students both at school and outside of school. The discipline of coming and going home will be considered and provide the material that needed the material mastery. Teachers were also required to master high child psychology so that in teaching, all components were met. And I hoped that what the teacher did was all only because of Allah SWT."

On the other hand the head of the madrasa said that:

"When I did clinical supervision at the madrasa which I led, some of the teachers were enthusiastic about self-reflection so high work motivation growth in the teacher's personality. This will have an impact on improving teacher performance. Before doing clinical supervision, I filled it with the speech. First, all of this was to grow a sense of belonging to the soul of the teacher whose task was carried out because of Allah, from here the teachers began to call his heart to do their duties without having to be called and received praise. However, there were still some teachers who still did not follow the existing rules, namely they did not do their duties properly, both administratively and in doing the teaching tasks."

Based on the interview above, the teachers had done their duties and responsibilities well, both administratively and teaching assignments in the classroom. As a teacher, of course, you were obliged to make a lesson plan (RPP) for teacher preparation in the teaching and learning process in the classroom by implementing the existing system in accordance with the curriculum, namely, starting from methods, techniques, class mastery and others. One teacher said:

"After clinical supervision was done, we began to have many teachers motivated to be self-aware in doing school assignments namely by improving themselves. This can be seen from several teachers who had prepared learning devices in the form of making lesson plans before teaching, choosing the right teaching methods and 
techniques, entering class according to the schedule that had been made, as well as leaving class according to the time specified that had been determined, and solving student problems without prompting. All of that was a form of self-reflection on some teachers and there was a good improvement regarding the performance of all teachers."

On the other hand Bielda says that:

"Spiritual quotient training was very influential for us (teachers), because after the implementation, we had a fear of Allah when we left the task, for that I felt that clinical supervision can reflect the soul of the teachers. Teachers were really called upon to do their duties according to the existing schedule."

According to the interview results mentioned above, if clinical supervision was based on a spiritual quotient by fulfilling the components of goals, procedures, and teacher performance assessments, then the achieved goals will automatically be realized, namely to improve teacher performance. Teacher performance was a combination of clinical supervision with a spiritual quotient. From this achievement, the teacher will automatically do his duties at the call of the soul because of Allah and on his awareness to improve the teacher's performance.

Spiritual quotient or spiritual intelligence was an intelligence that influenced the conscience factor of every human being/teacher who was also inspired to encourage a teacher to make the existence of Allah SWT more effective in his daily life by being able to unite his body, heart and mind (Sinetar, 2001). Spiritual quotient or spiritual intelligence was the light of the heart of every human being and the feeling from within when living his life, which was to unite his conscience and positive thoughts (Zohar \& Marshall, 2007). All of this was by the function of motivation, namely the existence of an impulse that came from within the soul, in the form of behaviour, character, desire, wanting to move forward, which can be proven in action and deed (Sardiman, 2012). From here, motivation will arise by itself and as a result of behavior and actions, for example, teacher motivation and student learning. Motivation can function as a tool to direct behaviour or actions towards achieving the desired goals better. Motivation also had a function as a driver. The size of motivation in humans depended on how fast or slow a person did a job (Hamalik, 2011).

Spiritual intelligence was an important factor to do the task because it will automatically grow awareness in his life by combining his conscience and mind. Here it can be seen that the Spiritual quotient was very important and affected the implementation of learning so that it can improve teacher performance. Even though this Spiritual quotient training was done once, it still greatly influenced the teacher's self-awareness of his responsibilities. Spiritual intelligence was intelligence to deal with problems of meaning or values, namely intelligence to place our behavior and life in the context of a broader and richer meaning, intelligence to judge that one's actions or way of life were more meaningful than others. Spiritual intelligence was the foundation needed to function IQ and EQ effectively (Fitriani \& Yanuarti, 2018; Ratnawati \& Puspitasari, 2013).

Several studies have shown that between emotional intelligence and spiritual intelligence. Spiritual intelligence dominated in influencing teacher performance (Sholiha et al., 2017). It had a significant effect on teacher performance (M. F. Abas et al., 2020; Ekowati et al., 2020; Khodijah \& Sukirman, 2014; Kurniawati et al., 2018; Priadi, 2018; Sonitra \& Ekowati, 2020). This showed that spiritual intelligence played a very important role in improving teacher performance with indicators of self-knowledge, self-control, motivation, empathy and social skills.

Teacher performance will run well when the teacher has mature spiritual intelligence and selfawareness in doing his duties, according to his duty function as a mentor, educator and teacher, greatly triggers the progress and retreat of an education (Baharuddin \& Zakaria, 2018). According to Surya, professional teachers will be reflected in the implementation of the dedication of tasks marked by expertise in both material and method. Thus, future teachers will no longer appear as teachers but take on the role of supervising trainers and managers of learning (Kunandar, 2007). 
Spiritual intelligence in humans as an inspired thought process that growth self-awareness. In each of clinical supervision based on Spiritual Quotient activity, the questionnaire integrated the following clinical supervision steps:

1. Stage of spiritual quotient training. At this stage, teachers, supervisors and principals attended spiritual quotient training devoted to fostering the spirituality of all teachers, principals and supervisors. At this stage, the training team was tailored to the needs of the teacher.

2. Early meeting stage. At the early/introductory meeting stage between the supervisor and all teachers involved in clinical supervision based on a spiritual quotient that discussed the learning process's shortcomings and weaknesses and made a list of identifying weaknesses themselves. All the teachers discussed in a good and friendly atmosphere, like a peer discussion. Those involved in this discussion were supervisors and teachers.

3. Teaching observation stage. After the early meeting was held, the supervisor and teacher got ready to do supervision in the classroom. The teacher and supervisor entered the classroom, the teacher taught while the supervisor sat at the back of the class while observing the teacher teaching, while other teachers in the same group observed the students studying one by one carefully. Supervisors must be able to carry themselves as well as possible.

4. The stage of the feedback meeting. After the class ended, the teacher and supervisor ended the supervision, so they went into a room that had been prepared in advance to have a discussion or feedback meeting. This feedback meeting was combined with the reflection stage in spiritual quotient, so that the teachers who were present at the teaching observation stage also entered the room and discussed together. The supervisor must be a good listener, give a great opportunity for the teacher to be able to tell his story and to be able to reflect on what he had done in the classroom, also must be able to respect the teacher's opinion.

5. Follow-up stage. At this stage, teachers who saw weaknesses were given guidance, spiritual guidance, motivation, and teaching competence development. The guidance that was done directly by the school through certain trainings was in accordance with the weaknesses of the teacher. This guidance was done continuously so that teachers received in-service training and a Learning Organization was formed in the school until the weaknesses of teachers can be addressed properly. As in figure 1: 


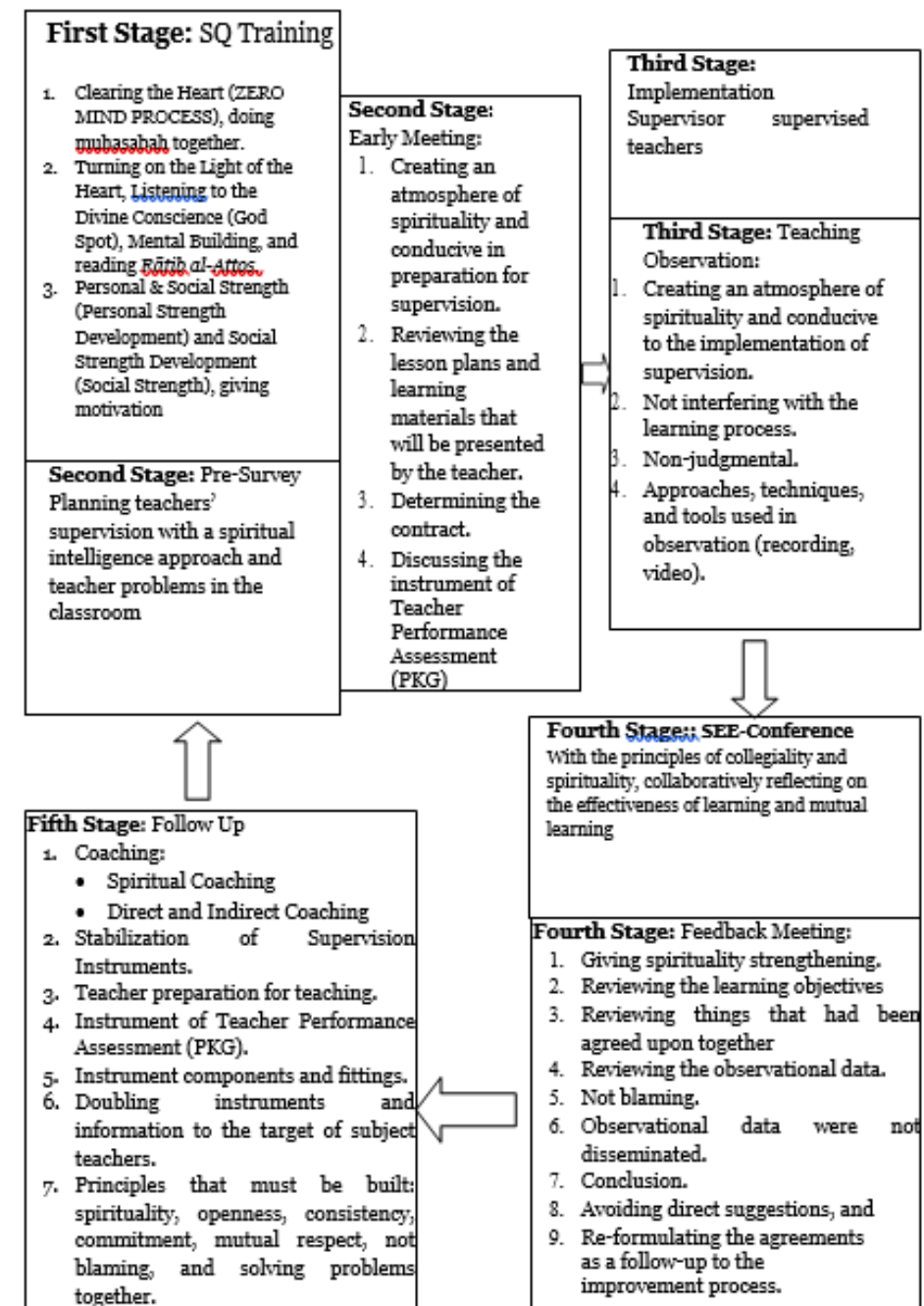

\section{Figure 1. Final Stage of clinical supervision based on Spiritual Quotient}

Spiritual quotient will have a positive impact on improving teacher performance. Clinical supervision based on Spiritual Quotient was a form of supervision that focused on improving teacher teaching performance, by going through several systematic stages of planning, careful observation, and intensive and careful analysis of the appearance of the real teacher teaching and learning process, which aimed to make major changes in an Islamic, religious, spiritual and rational way as well as motivating teachers from the deepest heart to correct all deficiencies in the teaching and learning process emphasizing on good teaching methods, namely effective, innovative and efficient learning.

The implementation of clinical supervision was expected to be able to change all the weaknesses and shortcomings of teachers, supervisors were also expected to not only look for shortcomings and weaknesses in teachers but supervisor was expected to provide high motivation in the form of solutions/problems to improve and increase the performance of all teachers so that teachers had high enthusiasm and motivation in doing their duties, especially in the teaching and learning process well.

From this formulation, it appeared that performance resulted from spiritual quotient, motivation and basic ability. Thus, people with a high spiritual quotient and high motivation will have a high spirit and responsibility in doing their duties and responsibilities. But if the teacher had a low spiritual quotient, low motivation, and low basic abilities, it would also result in low performance. Thus, the government really expected maximum teacher performance, which was a 
person can show his own high spiritual quotient ability and his high motivation will result in high performance. Therefore, to improve teacher performance, habituation and continuous guidance were needed in the form of clinical supervision based on spiritual quotients that can increase teacher motivation and abilities.

Teacher performance was the performance done by teachers in doing their duties as educators (Kakiay, 2018; Russamsi et al., 2020; Supardi, 2012). The quality of teacher performance will greatly determine the quality of educational outcomes, because the teacher was the one who had the most direct contact with students in the education/learning process at Madrasah educational institutions. Teacher performance was all the activities he did in doing his mandate and responsibility in educating, teaching and guiding, directing, and guiding students in reaching the level of maturity (Mukhtar, 2003). Thus, teacher performance was basically more focused on the behavior of an educator in his work and the effectiveness of educators in doing their duties and responsibilities which can influence students on goals (H. E. Abas, 2017).

Cogan was an expert who introduced clinical supervision to give a solution in improving teacher performance. According to him, clinical supervision was the right solution for teacher professional development in overcoming these problems. The clinical supervision approach was an observation that intended to improve teacher learning continuously and gradually (Supardi, 2012). Clinical supervision required a supervisor to come in to observe the teacher in the classroom while the teacher was learning. The main data was obtained from events in the classroom. The collected data was then analyzed and the relationship between teachers and supervisors will be used as the basis for forming programs, procedures, and strategies that improved teacher performance in learning.

This can also facilitate the feedback discussion process because it will be richer in input from the teacher team. Clinical supervision also had certain characteristics. Before the class observation process was done, it began with spiritual quotient training. The early meeting stage was united with a plan and was always filled with a spiritual atmosphere. That was, a supervisor always reminded teachers about the concept of Ihsan because Allah SWT at each stage of supervision and motivated teachers to always improve themselves and self-awareness without blaming other parties.

Clinical supervision based on Spiritual quotient certainly has advantages compared to the usual supervision, which was seen from the aspects of teacher motivation through strengthening spiritual intelligence or spiritual quotient (Agustian, 2008): 1) strengthening teacher motivation through the development of spiritual intelligence; 2) spiritual intelligence was the ability to give the meaning of worship to every behavior and activity, through steps and thoughts that were natural, towards a fully human (hanif), and had a monotheistic (integrality) thought pattern, and had the principle of "only because of Allah SWT".; and 3) a person's spiritual intelligence can increase when directed to discuss spiritual or religious topics such as istighfār, muhāsabah, dhikr and prayer.

According to McClelland, the role of spiritual intelligence was very important in inviting and guiding teachers to become the genuine self, original and authentic towards the ultimate truth, through a vertical approach to Allah SWT, as well as a horizontal approach, namely educating the hearts of teachers to have good character, wisdom, wise, and honest. With the combination of these two communication networks, it will be able to produce cool learning quality so as to produce a human resource figure who was loved, trusted, willing to sacrifice, committed, personable and trustworthy (Masaong, 2012).

Hendricks stated that the characteristics of teachers who had spiritual intelligence were 1) having integrity of faith (fitrah), 2) being professional and open, not discriminating against children in terms of ethnicity, race, and religion, 3) willing to accept criticism, 4) being humble, 5 ) able to respect others well (tolerant), 6) inspired by the vision, 7) knowing himself well, and 8) always strive for the best for himself and his students (Masaong, 2012).

The spiritual quotient training which was done as the beginning of the clinical supervision based on spiritual quotient process, gave satisfactory results. The teachers looked focused during the muhāsabah process and read the rātib al-'attós, and many even cried when they heard the prayers 
from the instructor. Then after the spiritual quotients training was completed, it was seen that the teachers openly accepted input from their supervisors and wanted to talk about their learning deficiencies. They were aware of the nature of teaching that was done only because of Allah SWT. They were also aware that teaching responsibilities will be questioned in the hereafter. Feeling lazy to write lesson plans, lazy to do good learning, everything will be questioned in the hereafter by Allah SWT.

The spiritual quotients training was proven to give "injection" and motivation to all teachers to give the best learning for their students and always try to improve themselves to become professional teachers. Teachers had been able to make lesson plans by showing the value of the Teacher Performance Assessment (PKG) which was continuously increasing. Clinical supervision based on spiritual quotient was an alternative to supervising madrasas. Spiritual quotient is a coaching strategy for the continuing educator profession through the principles of collegiality, mutual learning and learning community. With clinical supervision based on spiritual quotient, the teacher will get the following benefits:

a. The existence of togetherness and cooperation between teachers. So far, the implementation of clinical supervision was usually only done by a mediocre supervisor, so with the existence of clinical supervision based on spiritual quotient activities, the togetherness and comfort during clinical supervision was very much felt.

b. All teachers and students can observe carefully. If usually in ordinary clinical supervision only the teacher was the focus of the supervisor, then with clinical supervision based on spiritual quotient, students were also involved to pay attention to the teacher who was the observer, so that everything can be seen properly where there were students who were not paying attention in learning or not and what the reason was that students did not pay attention to learning.

c. Teachers can learn from their peers at school. Learning from peers was considered easier than learning from education experts who shared their knowledge in training activities or seminars. Learning from peers, the gaps in knowledge, experience, culture, and age were easier to address.

\section{CONCLUSION}

This research concluded that State Madrasah Aliyah of Way Kanan implemented regular clinical supervision in terms of early/introduction planning, class observation, and feedback discussion stages. The implementation of clinical supervision had not been done optimally because it had not reached the follow-up and continuous stage. After conducting clinical supervision based on a spiritual quotient, the teacher made several changes, including the teacher is open to receiving input, teaching as a responsibility, and making learning administration. Teacher self-awareness can improve teacher performance. The research implications for teachers were self-awareness, a strong desire to change for the better, and overcome obstacles.

\section{REFERENCES}

Abas, H. E. (2017). Magnet Kepemimpinan Kepala Madrasah Terhadap Kinerja Guru (Revisi) STO Mohon Banyak Disebar Di Lampung. Elex Media Komputindo.

Abas, M. F., Mardani, R. M., \& Priyono, A. A. (2020). Pengaruh Kecerdasan Emosinal dan Kecerdasan Spiritual Terhadap Kinerja Guru. Jurnal Ilmiah Riset Manajemen, 9(21).

Agustian, A. G. (2008). Rahasia Sukses Membangun ESQ Power, Sebuah Inner Journey Melalui Ihsan. Arga.

Aisyah T, N. (2017). Perbedaan persepsi kinerja guru pns dan non pns pada sekolah dasar negeri di desa saotengnga kabupaten sinjai. Universitas Islam Negeri Alauddin Makassar.

Andani, Y. S. B., Yulianto, A., \& Murwatiningsih, M. (2017). Model Supervisi Klinis Berbasis Teknologi Informasi dan Komunikasi Untuk Menigkatkan Kinerja Guru Produktif di SMKN 1 Kota Bima. Educational Management, 6(2), 163-169.

Arif, S. (2008). Implementasi supervisi klinis dalam pendidikan agama islam. TADRIS: Jurnal 
Pendidikan Islam, 3(2).

Arifin, Z. (2012). Evaluasi Pembelajaran. Remaja Rosdakarya.

Baharuddin, B., \& Zakaria, R. (2018). Pengaruh kecerdasan spiritual terhadap peningkatan kinerja guru di SMA Negeri 3 Takalar Kabupaten Takalar. Idaarah: Jurnal Manajemen Pendidikan, 2(1), 1-10.

Ekowati, S., Finthariasari, M., Yulinda, A. T., \& Sonitra, S. (2020). PENGARUH KECERDASAN INTELEKTUAL, KECERDASAN EMOSIONAL, DAN SPIRITUAL TERHADAP KINERJA GURU SDN KECAMATAN PINO BENGKULU SELATAN. (JEMS) Jurnal Entrepreneur Dan Manajemen Sains, 1(1), 10-19.

Fitriani, A., \& Yanuarti, E. (2018). Upaya Guru Pendidikan Agama Islam Dalam Menumbuhkan Kecerdasan Spiritual Siswa. BELAJEA: Jurnal Pendidikan Islam, 3(2), 173-202.

Hamalik, O. (2011). Proses Balajar Mengajar. Bumi Aksara.

Hoerotunnisa. (2021). The Komplesitas Sikap Profesional Guru Dalam Pembelajaran Jarak Jauh. AL-HIKMAH (Jurnal Pendidikan Dan Pendidikan Agama Islam), 3(2), 149-156.

Ibda, H. (2017). Peningkatan Kompetensi Profesional Guru Sd/Mi Melalui Menulis Di Media. Tarbawi: Jurnal Pendidikan Islam, 14(1).

Kakiay, A. N. (2018). Pengaruh kepemimpinan spiritual dan kepuasan kerja terhadap kinerja guru. Jurnal Psikologi, 1o(2).

Khodijah, N. (2013). Kinerja guru madrasah dan guru pendidikan agama Islam pasca sertifikasi di Sumatera Selatan. Jurnal Cakrawala Pendidikan, 5(1).

Khodijah, N., \& Sukirman, S. (2014). Hubungan Antara Kecerdasan Spiritual dan Self-Efficacy dengan Kinerja Guru Madrasah Aliyah Al-Fatah Palembang. Ta'dib: Jurnal Pendidikan Islam, 19(01), 1-22.

Kunandar. (2007). Implementasi Kurikulum KTSP. Raja Grafindo Persada.

Kurniawati, A. D., Sunaryo, H., \& Priyono, A. A. (2018). Pengaruh kecerdasan intelektual, kecerdasan emosional, dan kecerdasan spiritual terhadap kinerja guru (studi empiris pada guru MTs Darul Hikmah Ngompak, Ngawi, Jawa Timur). Jurnal Ilmiah Riset Manajemen, 7(03).

Lailatussaadah, L. (2015). Upaya Peningkatan Kinerja Guru. Intelektualita, 3(1).

Makhsun, N. (2020). Peningkatan Kinerja Guru MI Di Kecamatan Jumo Temanggung Dalam Penilaian Berbasis Kelas Melalui Supervisi Klinis. Wahana Akademika: Jurnal Studi Islam Dan Sosial, 7(1), 53-67.

Mansir, F. (2020). Kesejahteraan Dan Kualitas Guru Sebagai Ujung Tombak Pendidikan Nasional Era Digital. Jurnal IKA PGSD (Ikatan Alumni PGSD) UNARS, 8(2), 293-303.

Masaong, A. K. (2012). Pendidikan karakter berbasis multiple intelligence. Jurnal Konaspi VII Universitas Negeri Yogyakarta.

Mukhtar. (2003). Desain Pembelajaran Pendidikan Agama Islam. Misaka Galiza.

Muslim, S. B. (2017). Supervisi Pendidikan Meningkatkan Kualitas Profesionalisme Guru. Alfabeta.

Nastiti, S. M. (2016). Perbedaan Kinerja Guru Berdasarkan Status Kepegawaian PNS dan Non PNS di SMA Negeri Se-Kabupaten Rembang. Universitas Negeri Semarang.

Pidarta, M. (2009). Supervisi Pendidikan Kontekstual. Rineka Cipta.

Priadi, A. (2018). Pengaruh Kecerdasan Intelektual, Kecerdasan Emosional Dan Kecerdasan Spiritual Terhadap Kinerja Guru (. JURNAL SeMaRaK, 1(3). https://doi.org/10.32493/smk.vii3.2260

Putriasih, N. N. (2020). Implementasi Supervisi Klinis Berbasis Konsep Tri Hita Karana (THK) Untuk Meningkatkan Kinerja Guru. Journal of Education Action Research, 4(2), 185-191.

Ratnawati, \& Puspitasari, R. (2013). Psikologi Pendidikan. LP2 STAIN CURUP.

Rohmatika, R. V. (2017). Model Supervisi Klinis Terpadu Untuk Peningkatan Kinerja Guru Madrasah Aliyah. IAIN Raden Intan Lampung.

Russamsi, Y., Hadian, H., \& Nurlaeli, A. (2020). Pengaruh Kepemimpinan Kepala Sekolah Dan Peningkatan Profesional Guru Terhadap Kinerja Guru Di Masa Pandemi Covid-19. MANAGERE: Indonesian Journal of Educational Management, 2(3), 244-255.

Sardiman, M. (2012). Interaksi dan Motivasi Belajar Mengajar. Rajawali Pers.

Sari, S. I., Ngaba, A. L., Lalupanda, E. M., \& Aji, A. G. P. (2017). Pengendalian Dan Penjaminan Mutu Pengajaran Melalui Supervisi Klinis. Satya Widya, 33(1), 1-10.

Sholiha, M., Sunaryo, H., \& Priyono, A. A. (2017). Pengaruh Kecerdasan Emosional Dan Kecerdasan Spiritual Terhadap Kinerja Guru Smp An-Nur Bululawang-Malang. Jurnal Warta Ekonomi, 6(01). 
Simanjuntak, R. M., Simare-mare, A., \& Wau, Y. (2021). Implementasi Supervisi Klinis Berbasis Soft Skill Dalam Peningkatan Kinerja Guru. Prosiding Seminar Nasional Hasil Pengabdian Masyarakat: Kontribusi Perguruan Tinggi Dalam Pemberdayaan Masyarakat Di Masa Pandemi, 187-193.

Sinetar, M. (2001). Kecerdasan Spiritual (S. Boedidarmo (ed.)). Elex Media Komputindo.

Sonitra, S., \& Ekowati, S. (2020). Pengaruh Kecerdasan Intelektual, Kecerdasan Emosional, Dan Spiritual Terhadap Kinerja Guru. Jurnal Manajemen Modal Insani Dan Bisnis (JMMIB), 1(1), 1-10.

Supardi, S. (2012). Kinerja Guru. Rajawali Press.

Trisoni, R. (2016). Pengembangan Profesionalisme Guru dalam Mewujudkan Kualitas Pendidikan. Ta'dib, 14(2).

Zohar, D., \& Marshall, I. (2007). SQ-Kecerdasan spiritual. Mizan Pustaka. 